УДК 338.001 .36

\title{
ОБЗОРЫ
}

\author{
ФАКТОРЫ СТАБИЛЬНОСТИ ПЕНСИОННОЙ СИСТЕМЫ РОССИИ \\ Барышева Г.А., Бабышев В.Ю. \\ Школа инженерного предпринимательства Национального исследовательского \\ Томского политехнического университета, Томск, е-таil: ganb@tpu.ru,vacheslav84@mail.ru
}

В статье исследованы факторы стабильности пенсионной системы России как с точки зрения доходов, так и с точки зрения расходов. С точки зрения доходов рассмотрены такие факторы, как ставка страховых взносов, общая численность трудоспособного населения, уровень занятости и размер «теневого сектора» экономики. С точки зрения расходов рассмотрены такие факторы, как общая численность лиц пенсионного возраста, непрофильные расходы, а также коэффициент замещения средней пенсии средней зарплатой. Выявлено серьезное ухудшение коэффициента демографической поддержки за счет резкого увеличения численности пенсионеров. Напротив, не наблюдается заметного и катастрофического сокращения численности людей в трудоспособном возрасте. Выявлено, что привлечение иностранных мигрантов оказывает довольно слабое влияние на устойчивость пенсионной системы, а повышение пенсионного возраста ведет к повышению безработицы. Выявлен большой потенциал увеличения стабильности пенсионной системы в виде вывода зарплат на легальное положение, а также повышения уровня зарплат. Сделан вывод, что дефицит самой системы страховых пенсий по стажу заметно ниже дефицита всей пенсионной системы как за счет непрофильных расходов, так и за счет льготных досрочных пенсий.

Ключевые слова: пенсионная система, коэффициент демографической поддержки, коэффициент замещения, ставка страховых взносов, занятость, неформальная экономика, трудовые мигранты

\section{FACTORS OF STABILITY OF THE RUSSIAN PENSION SYSTEM}

Barysheva G.A., Babyshev V.Yu.

School of Engineering Entrepreneurship of the National Research Tomsk Polytechnic University, Tomsk,e-mail: ganb@tpu.ru,vacheslav84@mail.ru

\begin{abstract}
This article discusses the stability factors of the Russian pension system both in terms of income and expenditure. From the point of view of income, such factors as the rate of insurance premiums, the total number of working-age population, the level of employment and the size of the «shadow sector» of the economy are considered. From the point of view of expenses, factors such as the total number of persons of retirement age, non-core expenses, as well as the replacement rate of the average pension with an average salary are considered. A serious deterioration in the coefficient of demographic support due to a sharp increase in the number of pensioners was revealed. On the contrary, there is no noticeable and catastrophic reduction in the number of people of working age. It is concluded that attracting foreign migrants has a rather weak effect on the stability of the pension system, while raising the retirement age poses a danger of increasing unemployment. A great potential has been revealed for increasing the stability of the pension system in the form of bringing salaries to a legal position, as well as raising salaries. It is concluded that the deficit of the senior insurance pension system itself is noticeably lower than the deficit of the entire pension system due to non-core expenses and preferential early retirement benefits.
\end{abstract}

Keywords: pension system, coefficient of demographic support, replacement rate, insurance premium rate, employment, informal economy, labor migrants

В настоящее время в России практикуются три элемента пенсионной системы: накопительная (по факту временно заморожена), солидарная и базовая (платится всем людям, которые достигли пенсионного возраста, но не наработали стаж на обычную пенсию). В целом для большинства людей действует фактически солидарная система. Ее особенность заключается в том, что, хотя размер пенсий помимо базовой части определяется на основе расчетного пенсионного капитала застрахованного лица на основе его прошлых страховых взносов и ожидаемого периода выплаты трудовой пенсии по старости [1], фактически выплаты пенсий осуществляются на основе межбюджетных трансфертов и текущих страховых взносов.
Цель исследования: изучение факторов стабильности пенсионной системы России с целью выработки практических рекомендаций.

\section{Материалы и методы исследования}

Материалами для данной работы выступили статистические сборники, нормативные документы и аналитические статьи. Методами исследования послужил статистический анализ, сравнительно-исторический анализ, факторный анализ, сравнительный анализ данных и обзор литературы.

\section{Результаты исследования и их обсуждение}

Расходы на выплаты пенсий представляют собой произведение средней пенсии 
на общую численность пенсионеров. Общая численность пенсионеров фактически определяется только демографическими параметрами: прошлой рождаемостью и средней продолжительностью жизни, а точнее коэффициентом дожития до пенсионного возраста.

В целом увеличение средней продолжительности жизни резко увеличивает количество потенциальных пенсионеров и тем самым повышает расходы пенсионного фонда. По рождаемости ситуация не совсем однозначная: низкая рождаемость среди вышедшей на пенсию возрастной когорты снижает количество потенциальных пенсионеров и, наоборот, высокая рождаемость среди вышедшей на пенсию возрастной когорты подрывает текущую стабильность пенсионной системы. Уровень рождаемости возрастных когорт положительно сказывается на состоянии пенсионной системы при ее распространенности именно среди трудоспособного населения и отрицательно при ее распространении среди лиц пожилого возраста.

В свою очередь, доходы пенсионного фонда состоят из межбюджетных трансфертов и страховых взносов на пенсию. Целью проводимой реформы заявлено балансирование доходов и расходов пенсионной системы [2], поэтому остановимся подробнее на втором пункте. Общие доходы от страховых взносов зависят от двух параметров: ставки взносов в ПФ и размера налогооблагаемой базы. Ставка взносов может корректироваться в сторону увеличения, но данный резерв роста доходов ограничен кривой Лаффера: увеличение ставки взносов выше определенного уровня приводит к росту уклонений от выплаты взносов.

Размер налогооблагаемой базы зависит от общего числа работающих и их средней зарплаты, с размера которой работодатель уплачивает страховые взносы по обязательному пенсионному страхованию (ОПС). Общее число работающих в определенной степени зависит от общей численности трудоспособного населения, а этот показатель неизбежно ухудшается при падении рождаемости и старении населения из-за увеличения продолжительности жизни. Однако именно с точки зрения поступления страховых взносов в пенсионную систему следует обратить отдельное внимание на два нюанса: уровень занятости среди трудоспособного населения и процент легально работающих.

Рассмотрим более подробно коэффициент демографической поддержки. Общую численность трудоспособного населения и общее количество лиц пенси- онного возраста в специальной литературе рассматривают вместе через коэффициент демографической поддержки (соотношение численности лиц трудоспособного возраста к численности лиц старше трудоспособного возраста). Ситуация с численностью трудоспособного населения в России, вопреки общепринятому мнению, довольно благоприятная. Численность трудоспособного населения непрерывно росла до 90,2 млн чел. в 2006 г. и постепенно снижалась до 82 млн на 2018 г. При этом численность людей старше трудоспособного возраста неуклонно увеличивалась (4 млн или 2,1\% населения в 1940 г. и 46,5 млн или $31,7 \%$ в 2018 г. [3]), что в итоге обусловило ухудшение коэффициента демографической поддержки по всем методикам (в 1959 г. 17 пожилых на 100 человек в возрасте 2059 лет и 33 на 100 в 2014 г. [4]).

В 2019 г. по сравнению с 2005 г. этот коэффициент уменьшился с 3,1 до 2,2 человека трудоспособного возраста на одного пенсионера, а к началу 2036 г. снизится до 1,8. Если в середине прошлого века коэффициент демографической поддержки в России $(13,5)$ был выше не только стран $\mathrm{EC}(7,5)$, США $(7,9)$ и мира в целом $(11,9)$, то в середине 1990-х гг. оно сблизилось с данными странами: при коэффициенте поддержки в 5,5 в России этот показатель составил для США 5,2, Японии 4,9 и ЕС 4,5. И хотя ООН берет более широкий трудоспособный возраст в 15-64 года, ее оценки тоже показывают ухудшение коэффициента: 5,5 в 2009 г., 3,8 в 2018 г., 2,7 в середине века и 2,5 к концу века [5]. По другим прогнозам, нагрузка пожилыми вырастет с 196 на 1000 человек в возрасте 20-64 года в 2014 г. до 300365 на 1000 в 2030 г. [6].

Одним из вариантов улучшения данного показателя выдвигаются предложения по более активному привлечению иностранных трудовых мигрантов, большинство которых работают нелегально и не платят взносы в пенсионный фонд. Например, по данным Ю. Флоринской, в 2013 г. 3 млн иностранных мигрантов трудились легально, что составляло всего $4 \%$ от занятого населения РФ [7]. Учитывая, что мигранты в основном заняты на неквалифицированных работах с низкой оплатой, доходы ПФ от легальных мигрантов были еще ниже их процента в трудоспособном населении. Если же учитывать, что примерно столько же мигрантов трудилось нелегально, то издержки ПФ от занятого мигрантами «серого сектора экономики» покрывают весь доход. По данным Е. Щербаковой, число легально работающих мигрантов колебалось от долей процента в 1994 г., подня- 
лось до 4,4\% в 2014 г. и снизилось до $2,4 \%$ к концу 2018 г. [8]. Таким образом, потенциал пополнения пенсионного фонда от работающих легальных мигрантов довольно незначителен и составлял не больше $4,4 \%$ от общей численности работающих даже без учета их пониженной зарплаты.

Доходы пенсионной системы прямо пропорциональны уровню зарплат, которые в свою очередь зависят от производительности труда. В исследовательских работах этот показатель входит в состав коэффициента эффективной экономической поддержки, который рассчитывается на основе показателя эффективного работника и эффективного потребителя. Согласно расчетам М. Денисенко, по среднему варианту демографического прогноза Института демографии НИУ ВШЭ коэффициент эффективной экономической поддержки уступает двум другим коэффициентам поддержки, а в период с 2017 по 2050 г. будет постепенно снижаться от 0,6 до 0,4. Иными словами, при сохранении нынешнего уровня производительности труда в России совокупные денежные доходы населения с учетом возрастных профилей будут колебаться в диапазоне от 60 до $40 \%$ от всех совокупных денежных расходов населения с учетом возрастных профилей при неизменности других параметров (в частности, срока выхода на пенсию). При неизменной производительности труда дефицит жизненного цикла (превышение суммарных расходов всех возрастных профилей над суммарными доходами всех возрастных профилей) составит в 2017 г. 4,5\% от ВВП, в 2025 г. в зависимости от низкого, среднего или высокого варианта демографического прогноза 9,$4 ; 10,0$ и $10,1 \%$ от ВВП соответственно, в 2035 г. данный показатель будет составлять 11,$7 ; 13,7$ и $13,9 \%$, а в 2050 г. - 13,5; 16,5 и $18,0 \%$ [9].

Имеющиеся оценки показывают значительный объем теневого сектора экономики. Министр финансов А. Силуанов оценил объем серой зарплаты в России в более чем 10 трлн руб. в год, что составляет треть всего зарплатного фонда [10]. С учетом ставки страховых взносов в 22\% это дополнительные 2,2 трлн руб. в год страховых взносов или 68,75\% от всех поступивших страховых взносов в 2017 г. Согласно заключению Комитета Государственной Думы по бюджету и налогам на проект федерального закона № 489161-7 «О внесении изменений в отдельные законодательные акты Российской Федерации по вопросам назначения и выплаты пенсий», в 2018 г. при общей численности населения в трудоспособном возрасте в 82,3 млн чел. численность работающих, за которых работодатель уплачивал страховые взносы по ОПС, составляла только 53 млн человек (64,4\% трудоспособного населения). При этом согласно данному заключению, именно соотношение платящих страховые взносы по ОПС к общей численности пенсионеров определяет величину межбюджетных трансфертов, необходимых для покрытия дефицита пенсионной системы. Впрочем, за последние годы заключение отмечает определенный рост собираемости страховых взносов: за 2017 г. при сохранении неизменной ставки поступление страховых взносов увеличилось на 8,7\% или на 358,6 млрд руб. больше уровня 2016 г. [3].

Подводя итоги, отмечаем, что теневая экономика представляет собой огромный резерв повышения доходов как пенсионной системы в частности, так и бюджета страны в целом. Для конкретно пенсионной системы это позволит увеличить доходы в виде собранных страховых взносов почти в 2 раза по максимальной оценке и сократить в несколько раз межбюджетные трансферты, направляемые на устранение дефицита ПФ. И. Терентьева оценивает доход ПФ от вывода зарплат из тени в $10-15 \%$ или в 400-600 млрд руб. в год $(0,5-0,75 \%$ ВВП) [11].

Самым простым и быстрым способом решения дефицита пенсионного фонда является повышение пенсионного возраста, в ходе которого механически сокращается численность пенсионеров и автоматически повышается численность трудоспособного населения. Например, по оценкам С. Иванова современная реформа приведет к увеличению численности трудоспособного населения на 5,4 млн чел. до 81,4 млн в 2030 г. вместо равномерного сокращения на аналогичную цифру. В частности, к 2034 г. число пенсионеров будет на 8,2 млн меньше по сравнению с моделью без реформы. Однако данный эффект временный и для продолжения существующей динамики потребуется постоянно повышать возраст выхода на пенсию вслед за старением населения, в противном случае эффект от реформы очень быстро будет исчерпан [2].

Также экономическая выгода от метода зависит от дальнейшей судьбы отложивших выход на пенсию людей: продолжение работы или выход на пособия по безработице. Если предпенсионеры не смогут найти работу, то государству придется выделять дополнительную социальную помощь уже безработным. Уже запланировано, что неработающие люди предпенсионного возраста будут получать повышенное пособие по безработице в 11 тыс. руб. в месяц, что 
меньше средней пенсии. Таким образом, хотя государство частично смягчает последствия реформ, но благосостояние не вышедших на пенсию людей снизится. Как уже отмечалось выше, существует проект переложения расходов с государства на детей пенсионеров, но такой вариант резко ухудшит благосостояние молодежи [2].

Повышение пенсионного возраста даже при обещании правительства ежегодно увеличивать пенсию на 1 тыс. руб. сможет сэкономить значительную сумму: по оценкам С. Иванова 170 млрд руб. в 2019 г., а за период 2019-2030 гг. - более 9 трлн руб. При этом при условии $80 \%$ занятости бюджет получит 4,7 трлн руб. взносов и подоходных налогов на 2,8 трлн руб. При этом в 20192020 гг. на повышенное пособие по безработице придется истратить 240 млрд руб., а в 2019-2030 гг. - 2,2 трлн руб. В итоге реформы государство получит доход в виде 5,2 трлн руб. за 12 лет, но с другой стороны увеличение пенсий на 1 тысячу в год приведет к дополнительным расходам в размере 29 трлн руб. за период 2019-2030 гг. В целом данные цифры очень сильно зависят от занятости людей предпенсионного возраста: один безработный приведет к убыткам государства в 30 тыс. руб. в год. Доходы пенсионеров от ежегодного повышения пенсии на 1 тыс. руб. будут превосходить ежегодную индексацию при условии инфляции не выше $4 \%$ в год и увеличения реальных зарплат меньше $1 \%$ в год. Но даже в этом случае доходы уже вышедших на пенсию людей только временно превысят размер пенсий при прежней модели и будут убывать по мере сокращения доли 1 тыс. руб. в общей пенсии [2]. Однако, по мнению И. Терентьевой, повышение пенсионного возраста будет иметь только временный эффект, после чего в долгосрочной перспективе расходы пенсионного фонда увеличатся из-за повышения объема пенсионных прав от увеличенного периода трудового стажа [11]. Повышение пенсионного возраста поддерживается и в заключении Комитета Государственной Думы по бюджету и налогам на проект федерального закона № 489161-7 «О внесении изменений в отдельные законодательные акты Российской Федерации по вопросам назначения и выплаты пенсий». Согласно данному заключению повышение пенсионного возраста позволит увеличить средний размер пенсий в 2019 г. на 1 тыс. руб. (7\%), а к 2024 г. более чем на $30 \%$ по сравнению с 2018 г. [3].

Одним из факторов, которые определяют стабильность пенсионной системы, является ставка страховых взносов. С одной стороны, низкий уровень ставок ухудшает параметры пенсионной системы, требуя изменения других факторов или финансирования со стороны государства. С другой стороны, повышение ставок ограничено кривой Лаффера, когда после перехода через критическую точку собираемость взносов резко падает. В целом, в отличие от экономических и демографических факторов, ставки взносов в большей степени регулируются административными решениями государства.

Согласно данным О. Синявской, в советское время пенсии финансировались из общественных фондов потребления, которые имели два источника финансирования: финансирование из государственного бюджета и отчисления предприятий в размере от 4 до 12\% от фонда оплаты труда. Если взять ставку взносов в $4 \%$ и коэффициент замещения средней пенсии средней зарплатой в $33 \%$, то для устойчивой работы пенсионной системы без помощи государства нужно не меньше 8,25 работников на одного пенсионера в каждый момент времени. Если считать приемлемым коэффициент замещения в $50 \%$, то для стабильности пенсионной системы при ставке взносов в $4 \%$ потребуется уже 12,5 работников на одного пенсионера. С $12 \%$ ситуация выглядит чуть лучше. При ставке взносов в $12 \%$ и коэффициенте замещения в $33 \%$ на каждого пенсионера потребуется 2,75 работника, а при коэффициенте замещения в $50 \%$ уже 4,17 работников. Именно быстрое увеличение численности пенсионеров с 13,7 млн до 33,8 млн с 1961 по 1990 гг. при сохранении низкой ставки отчислений с фонда оплаты труда привели к первому кризису в истории пенсионной системы России. К 1980 г. участие государства в финансировании расходов на пенсии достигло $60 \%$, а в 1980-х гг. из-за дефицита бюджета в $10 \%$ от ВВП состояние пенсионной системы еще более ухудшилось [12].

По данным Н. Кузнецовой, в самом начале 1990-х гг. фактический тариф взносов от исходного уровня в $26 \%$ поднялся до $31,6 \%$ в 1991-1992 гг., составив тем самым исторический рекорд [13]. При коэффициенте замещения в $33 \%$ и ставке взносов в $31,6 \%$ для стабильности пенсионной системы требуется всего 1,04 работник на пенсионера, а при коэффициенте замещения в $50 \%$ только 1,58 работник. Для ставки взносов в $26 \%$ и коэффициенте замещения в $33 \%$ нужно 1,269 работников на одного пенсионера, а для коэффициента замещения в $50 \%$ нужно 1,923 работника.

Согласно закону 1990 г. размер взносов для предприятий был повышен до $28 \%$ от фонда оплаты труда, а для работников 
отдельно на уровне в $1 \%$ от заработной платы. С 1993 г. до введения единого социального налога ставка взносов для работодателей в целом оставалась на уровне $28 \%$, а $1 \%$ взносов от работников был одновременно отменен в 2000 г. При коэффициенте замещения в 33,7\% в 1990 г. и суммарной ставки взносов в 29\% для стабильности пенсионной системы требовалось уже 1,16 работников на одного пенсионера. При допустимом коэффициенте замещения в $50 \%$ и ставке взносов в $29 \%$ для стабильности пенсионной системы требуется уже 1,724 работников на одного пенсионера. В 1992-1994 г. в условиях высокой инфляции и резкого роста численности пенсионеров тарифы постоянно пересматривались. В итоге, в 1992-1994 гг., невзирая на постоянную индексацию пенсий, доходы ПФ стабильно превышали его расходы. Однако в дальнейшем стал наблюдаться резкий рост неплатежей из-за финансово-экономических трудностей, поэтому высокие ставки уже перестали спасать пенсионную систему [12].

В период с 2002 по 2010 г. в рамках единого социального налога тариф страховых взносов на пенсию составлял от 8 до $11 \%$. При ставке взносов в $8 \%$ и допустимом коэффициенте замещения в $33 \%$ для стабильной работы ПФ нужно 4,125 работающих на одного пенсионера, а при коэффициенте замещения в 50\% уже 6,25 работающих. При ставке взносов в $11 \%$ и коэффициенте замещения в $33 \%$ для стабильной работы ПФ нужно 3 работника на одного пенсионера, а при коэффициенте замещения в 50\% по 4,545 работников.

После отмены единого социального налога тариф взносов на выплату пенсий резко повысился к 2011 г. через промежуточные $14 \%$ до 20\%. При допустимом коэффициенте замещения в $33 \%$ и ставке взносов в 20\% для стабильности пенсионной системы нужно по 1,65 работников на одного пенсионера, а при коэффициенте замещения в $50 \%$ уже требуется 2,5 работника. При ставке взносов в $14 \%$ и допустимом коэффициенте замещения в $33 \%$ для стабильности пенсионной системы нужно 2,357 работающих на одного пенсионера, а для коэффициента замещения в $50 \%$ требуется 3,571 работающих. После достижения величины 20\% ставка взносов упала на пару лет до 16\% и потом поднялась до современных 22\%. При коэффициенте замещения в $33 \%$ и ставке взносов в $16 \%$ для стабильности пенсионной системы требуется 2,06 работников на пенсионера, а для коэффициента замещения в 50\% уже 3,125 работников. Ставки взносов составля- ют с 2014 г. 22 \%. При допустимом коэффициенте замещения в $33 \%$ для стабильности пенсионной системы нужно 1,5 работающих на одного пенсионера, а при допустимом коэффициенте замещения в $50 \%$ уже 2,72 работающих на одного пенсионера при $100 \%$ белых зарплатах. По данным О. Синявской, после 1994 г., невзирая на все ухищрения властей, состояние пенсионной системы продолжало ухудшаться, невзирая на изменения ставки взносов в ПФ. Из чего делаем вывод, что увеличение ставки взносов дало эффект только на самых ранних этапах развития рыночной экономики России, видимо, из-за отсутствия привычки уклоняться от уплаты налогов вне зависимости от их размера, а потом даже снижение ставки взносов не приводило к увеличению процента собираемости. И. Терентьева обращает внимание на тот факт, что, хотя официальной ставкой установлены $22 \%$, но отдельным видам страхователей установлены льготные тарифы. Например, с зарплаты выше определенного порогового уровня, взносы в ПФ взимаются по ставке $10 \%$. В связи с этим она предлагает либо повысить пороговой уровень для зарплат по льготной ставке, либо увеличить сам размер этой ставки [11].

Согласно заключению Комитета Государственной Думы по бюджету и налогам на проект федерального закона № 489161-7 «О внесении изменений в отдельные законодательные акты Российской Федерации по вопросам назначения и выплаты пенсий» в России наблюдается самая высокая нагрузка на фонд оплаты труда (для работодателей $30 \%$ в России против от $0,0 \%$ в Швеции до 20,3-26,6\% в Великобритании), поэтому ресурс в виде повышения ставки взносов исчерпан [3]. Размер пенсий оказывает обратно пропорциональное влияние на расходы и устойчивость пенсионной системы. Однако чрезмерное сокращение пенсий чревато социальными потрясениями и недовольствами. Вероятно, максимальный резерв реформ в этой сфере определяется соотношением средней пенсии к прожиточному минимуму пенсионера.

Точные данные о соотношении среднего размера пенсий к прожиточному минимуму пенсионера есть с 1992 г. Значение этого показателя по данным О. Синявской в 1993-2007 гг. представлено в табл. 1. Однако В. Ляшок, В. Назаров и М. Орешкин приводят немного другие цифры (табл. 2).

По данным О. Кувшиновой, Ф. Стеркина и А. Прокопенко, в 2014-2016 гг. соотношение средней пенсии к средней зарплате сократилось до 1,5 [15]. По данным Е. Щербаковой в 2017 г. соотношение немного 
повысилось до уровня чуть ниже 1,6 [16]. При этом, по данным А. Соловьева, в 2015 г. средний размер трудовой (страховой) пенсии по старости составлял 161,1\% от прожиточного минимума пенсионера (ПМП), а средний размер трудовой (страховой) пенсии составлял 155,5\% от ПМП [17]. Одним из результатов пенсионной реформы заявлено повышение среднего размера страховых пенсий в долгосрочном периоде до 2,5-3 от прожиточного минимума пенсионера, поэтому данный показатель станет еще более обременительным для пенсионной системы. И. Терентьева согласна с тем, что ограничение размера пенсий невозможно для России ввиду их низкого размера. В России пенсией замещается только $35 \%$ от среднего заработка, а в странах ОЭСР 40,6\%.

Таблица 1

Реальный размер назначенной пенсии, отношение средней пенсии к прожиточному минимуму пенсионера и коэффициент замещения в 1990-2007 гг. в \% по данным О. Синявской

\begin{tabular}{|c|c|c|c|}
\hline Годы & $\begin{array}{c}\text { Реальный размер пенсии } \\
(1990=100)\end{array}$ & $\begin{array}{c}\text { Отношение средней пенсии } \\
\text { к прожиточному минимуму }\end{array}$ & $\begin{array}{c}\text { Коэффициент замещения } \\
\text { (средняя пенсия к средней зарплате) }\end{array}$ \\
\hline 1990 & 100 & & 33,7 \\
\hline 1991 & 97,0 & 125,2 & 33,8 \\
\hline 1992 & 50,3 & 138,0 & 27,3 \\
\hline 1993 & 65,8 & 128,6 & 33,9 \\
\hline 1994 & 63,7 & 101,0 & 35,6 \\
\hline 1995 & 51,3 & 116,0 & 39,8 \\
\hline 1996 & 55,7 & 113,2 & 38,2 \\
\hline 1997 & 52,7 & 114,7 & 34,5 \\
\hline 1998 & 50,2 & 70,2 & 29,5 \\
\hline 1999 & 30,4 & 76,4 & 31,2 \\
\hline 2000 & 38,9 & 89,5 & 31,6 \\
\hline 2001 & 47,3 & 100,0 & 31,6 \\
\hline 2002 & 55,0 & 102,0 & 29,8 \\
\hline 2003 & 57,4 & 106,3 & 28,4 \\
\hline 2004 & 60,6 & 97,8 & 27,6 \\
\hline 2005 & 66,4 & 99,8 & 25,8 \\
\hline 2006 & 69,8 & 99,7 & 22,8 \\
\hline 2007 & 72,4 & & \\
\hline
\end{tabular}

Таблица 2

Динамика реального размера назначенных пенсий, коэффициента замещения, отношения средней пенсии к прожиточному минимуму пенсионера в 2002-2014 гг. по данным В. Ляшок, В. Назарова и М. Орешкина [14]

\begin{tabular}{|c|c|c|c|c|c|}
\hline Годы & $\begin{array}{c}\text { Средний раз- } \\
\text { мер трудовой } \\
\text { пенсии, руб. }\end{array}$ & $\begin{array}{c}\text { Реальный раз- } \\
\text { мер назначен- } \\
\text { ной пенсии\% }\end{array}$ & $\begin{array}{c}\text { Коэффициент } \\
\text { замещения, } \%\end{array}$ & $\begin{array}{c}\text { Скорректирован- } \\
\text { ный коэффициент } \\
\text { замещения, } \%\end{array}$ & $\begin{array}{c}\text { Отношение пенсии } \\
\text { к прожиточному мини- } \\
\text { муму пенсионера, \% }\end{array}$ \\
\hline 2002 & 1396 & 118 & 32,0 & 47,1 & 101,2 \\
\hline 2003 & 1660 & 125 & 30,2 & 49,5 & 103,4 \\
\hline 2004 & 1945 & 131 & 28,9 & 43,0 & 108,0 \\
\hline 2005 & 2395 & 146 & 28,0 & 40,0 & 99,0 \\
\hline 2006 & 2770 & 155 & 26,0 & 37,2 & 101,4 \\
\hline 2007 & 3168 & 158 & 23,3 & 31,2 & 103,4 \\
\hline 2008 & 4286 & 189 & 24,8 & 33,4 & 117,6 \\
\hline 2009 & 5323 & 216 & 28,6 & 39,0 & 129,8 \\
\hline 2010 & 7811 & 291 & 37,3 & 51,9 & 169,1 \\
\hline 2011 & 8510 & 299 & 36,4 & 49,3 & 183,6 \\
\hline 2012 & 9405 & 310 & 35,3 & 46,9 & 171,9 \\
\hline 2013 & 10313 & 319 & 34,6 & 46,8 & 175,5 \\
\hline 2014 & 11151 & 302 & 34,3 & 45,1 & \\
\hline
\end{tabular}


Помимо повышения пенсионного возраста существует еще один способ уменьшения потенциального числа пенсионеров, а именно ужесточение требований к стажу для получения страховой пенсии по старости. И хотя не получившие страховую пенсию люди имеют обязательное право на социальную пенсию, размер социальной пенсии заметно ниже пенсии по старости.

С 2015 г. право на получение страховой пенсии по старости определяется на основе минимально необходимого стажа и величины пенсионных баллов, которые оценивают каждый год легальной работы человека по размеру уплачиваемых работодателей страховых взносов. По данной T. Павловой в рамках пенсионной реформы предусмотрено увеличение минимально необходимого стажа с 5 лет в 2015 г. до 15 лет к 2024 г. Заодно планируется увеличение необходимых пенсионных баллов с 6,6 в 2015 г. на 2,4 каждый год до 30 баллов в 2025 г. При этом минимальный стаж планируют повышать и после 2024 г. до 20 лет, а минимальное количество баллов увеличить до 52. При этом социальную пенсию планируют назначать только с 68 лет. Заодно планируется ужесточить получение некоторых категорий досрочных пенсий: минимально необходимый стаж для досрочного выхода на пенсию для учителей и врачей повысить с нынешних 25 до 35 лет. При этом уже в 2019 г. для получения страховой пенсии необходимо будет иметь не менее 10 лет страхового стажа и не менее 16,2 пенсионных баллов [18]. Что касается такого пути сокращения пенсионных расходов, как прекращение индексации и перерасчета пенсий работающим пенсионерам, то в результате этой меры резко снизилось коли- чество работающих пенсионеров - с $36 \%$ в 2015 г. до $22 \%$ в начале 2018 г. [16].

Специфика пенсионного фонда России, в отличие от некоторых западных систем, состоит в отсутствии собственного механизма накопления денег: по сути ПФ занимается исключительно перераспределительными функциями между поступлениями страховых взносов с работодателей и межбюджетными трансфертами, с одной стороны, и выплатой пенсий, с другой. Однако при отсутствии собственных источников дохода, на ПФ России возложены некоторые непрофильные социальные расходы, которые не связаны напрямую с выплатой страховых пенсий по старости лет. Эти расходы не связаны со старением населения и поэтому размывают убытки пенсионной системы от отдельно демографических изменений.

Распределение по отдельным видам непрофильных расходов последний раз встречается в проекте бюджета ПФ на 2014 г. [19]. В частности, на выплату материнского капитала из средств ПФ было направлено 270,7 млрд руб., на ежемесячные денежные выплаты отдельным категориям граждан (ЕДВ) потрачено 341,4 млрд руб., выплаты неработающим трудоспособным лицам, которые в виде родителей или опекунов ведут уход за ребенком-инвалидом, составили 25,3 млрд руб. В дальнейших проектах бюджета ПФ раскладки на отдельные виды непрофильных расходов уже не встречаются, но есть общие цифры. В бюджете за 2016 г. расходы на социальные выплаты от пенсионного фонда составили уже 572 млрд руб. или 7,3\% в общем объеме расходов [20]. В 2017 г. социальные выплаты составили 488 млрд руб. или 5,9\% в общем объеме расходов [21].

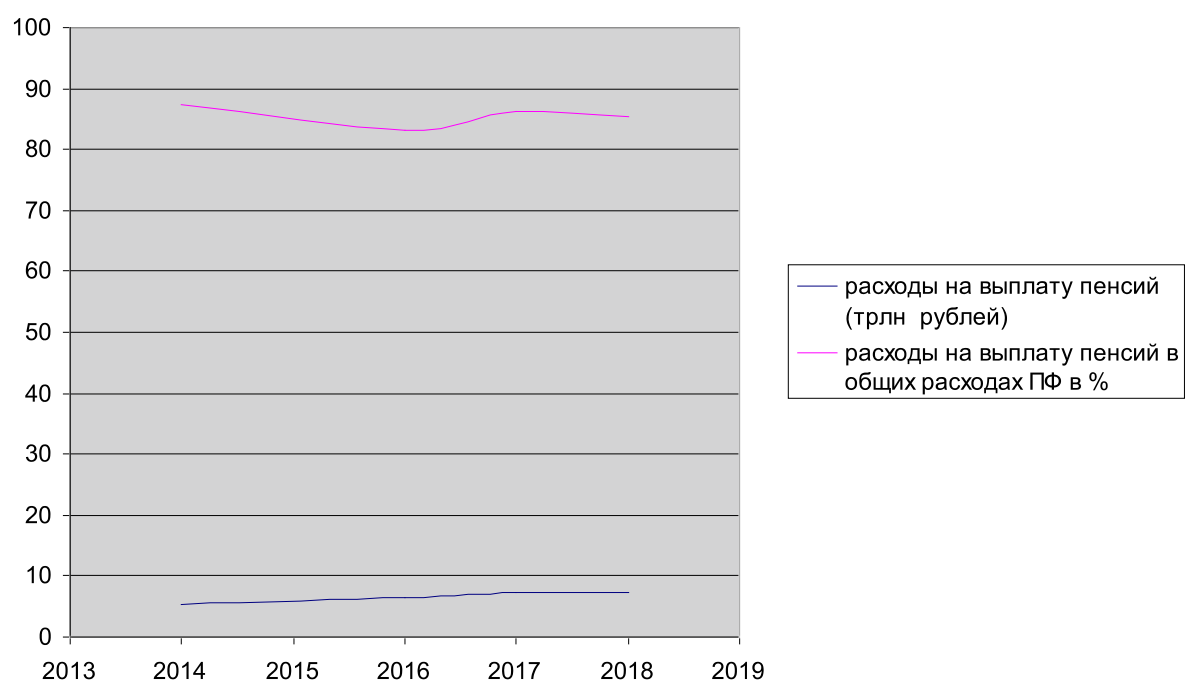

Рис. 1. Расходы на выплату пенсий в общей структуре расходов ПФ[22] 


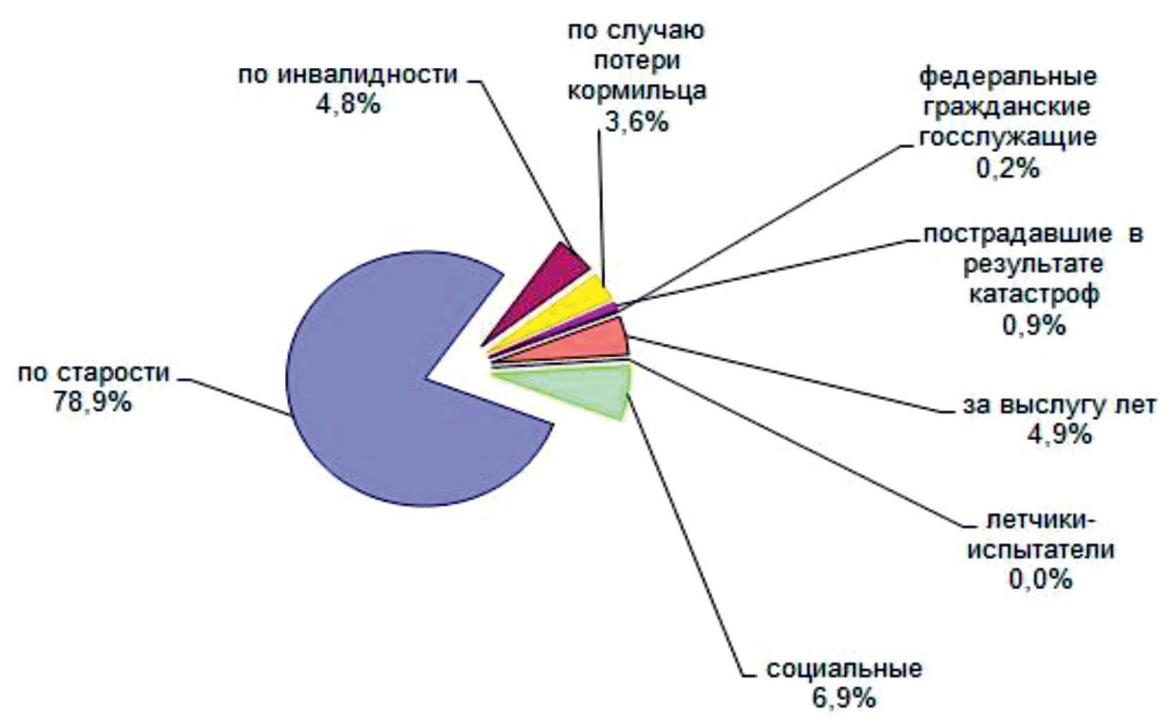

Рис. 2. Распределение пенсионеров России по видам назначенной пенсии по данным Е. Щербаковой на начало 2018 г. в\%

Помимо непрофильных расходов существуют отдельные виды пенсий, не связанные напрямую с наступлением страхового случая достижения пенсионного возраста. Раскладку по отдельным видам пенсий приводит в своей статье Е. Щербакова. По состоянию на 2018 г. численность людей старше трудоспособного возраста превысила 37 млн человек (25\% населения России), но при этом число получателей пенсий превысило 46 млн человек (на 23\% больше численности пенсионеров по старости).

Таким образом, больше $21 \%$ пенсий платились не по старости. Впрочем, в связи с непропорциональностью размеров пенсий, расходы на отдельные виды пенсий тоже не вполне пропорциональны численности получателей. Согласно Е. Щербаковой, при средней пенсии в 13323 рубля размер пенсий по старости составлял 14152 рубля, по инвалидности 8 807, по случаю потери кормильца 8876 , пенсии пострадавшим в результате катастроф 11863 , пенсии федеральным гражданским госслужащим 18710 и социальные пенсии 8807 руб. в месяц [16]. Таким образом, на пенсии по старости тратилось $83,7 \%$ от всех пенсионных расходов.

В целом, наверное, имело бы смысл рассматривать пенсии по старости и страховые взносы по ОПС самостоятельно, чтобы видеть отдельно убытки от старения населения. Коэффициент покрытия пенсий по старости страховыми взносами начал рассчитываться с бюджета ПФ 2017 г. В 2017 г. страховые пенсии по старости были бо- лее чем на $70 \%$ обеспеченны собранными взносами. В 2018 г. собранные взносы обеспечили $73 \%$ от выплаченных страховых пенсий. Характерно, что направляемый государством межбюджетный трансферт для покрытия расходов ПФ заметно больше. В 2017 г. при общем размере расходов ПФ в 8319,5 млрд руб. поступление взносов на обязательное пенсионное страхование составило 4481,9 млрд руб. или $53,87 \%$ от всех расходов ПФ. Таким образом, межбюджетный трансферт в 2017 г. покрыл $46,13 \%$ от всех расходов ПФ, при этом межбюджетный трансферт на покрытие именно страховой пенсии составил меньше $30 \%$. В 2018 г. при общем размере расходов ПФ в 8 428,7 млрд руб. поступление взносов на обязательное пенсионное страхование составило 4948,4 млрд руб. или $58,71 \%$ от всех расходов ПФ. Таким образом, межбюджетный трансферт в 2018 г. покрыл $41,29 \%$ от всех расходов ПФ, при этом межбюджетный трансферт на покрытие именно страховой пенсии составил всего $27 \%$.

Некоторые авторы обращают внимание на расходы на собственное содержание пенсионного фонда. Численность сотрудников ПФ России составляет 121670 чел. - первое место в мире. На втором месте Social Security Administration США с 60 тыс. paботающих на 61,5 млн пенсионеров, при этом объем пенсионных и социальных выплат почти в 9 раз больше. Nihon Nenkin Kikou Японии при сходной численности населения имеет 27 тыс. сотрудников, из них штатных всего 15 тыс. При этом получателей 
пенсий в Японии всего 39,4 млн человек при застрахованности 67,4 млн работников. Повышенные расходы на офисные здания определяются не только численностью работников, но и повышенными нормативами: по данным СП на одного работника фонда в среднем приходится по 17,4 кв. м. рабочей площади при 9 кв. м. площади на одного сотрудника в федеральных органах власти и по 4,5 кв. м. на одного сотрудника по нормам СаНПиНа. По заявлению шведского экономиста А. Ослунда при экстраполяции шведской системы штат пенсионного фонда России не должен был бы превышать 14 тыс. чел. Впрочем, в самом ПФ опровергли данное сравнение и заметили, что функционал фонда намного больше просто выплаты пенсий, в частности он занимается обработкой данных и расчетом будущей пенсии для 100 миллионов жителей России. Однако по данным рейтинга «Денег» ПФ по соотношению годового объема выплат и численности сотрудников ПФР оказался на 3 месте по неэффективности, а по соотношению численности работников пенсионных служб к количеству пенсионеров и получателей социальных выплат на 5 месте. В целом А. Зотин и М. Кваша пришли к выводу, что производительность труда в ПФР в плане выплат на одного работника можно увеличить в 10-15 раз [23]. Ради объективности стоит отметить, что, хотя по эффективности расходов ПФ занимает далеко не лучшие места, расходы на содержание самого ПФ составляют довольно скромную сумму в общем объеме расходов. Например, по данным С. Суховой в 2017 г. на содержание и функционирование ПФР было потрачено 111,7 млрд руб. [24]. При общих расходах ПФР в 8319,5 млрд руб. расходы на собственное содержание составляют всего $1,34 \%$.

Таким образом, большую часть расходов ПФР, не связанную напрямую с демографическим старением, составляют выплаты пенсий не по старости. На втором месте находятся различные социальные выплаты, вообще не связанные с начислением пенсий. Расходы же на содержание самого ПФ составляют ничтожную сумму в общем размере расходов, поэтому повышение эффективности работы фонда окажет крайне незначительное влияние на снижение расходов.

\section{Выводы}

Таким образом, ситуация с соотношением населения в трудоспособном возрасте к населению старше трудоспособного возраста однозначно ухудшается с точки зрения стабильности пенсионной системы.
В целом можно сделать вывод, что, вопреки распространенному мнению, активное привлечение иностранных мигрантов не приносит значительного увеличения дохода пенсионного системе, а с учетом недополученных от серого сектора экономики сборов прибыль от мигрантов оказывается не больше убытка от них.

Огромным и малоизвестным резервом повышения доходности пенсионной системы является возможный вывод на легальное положение теневого сектора экономики и повышение занятости трудоспособного населения. Эта мера способна погасить практически весь текущий дефицит именно по страховой части пенсионной системы.

Также в России наблюдается очень низкий уровень оплаты труда, и в этой сфере есть огромный потенциал для роста доходности пенсионной системы. Повышение пенсионного возраста и ужесточение условий назначения пенсий по старости тоже улучшит финансовое состояние пенсионной системы, однако эта мера чревата опасными последствиями, например, в виде увеличения безработицы и расходов на выплату пособий. При этом размер пенсий и ставка взносов выглядят малоперспективными в плане резервов роста устойчивости пенсионной системы. Также выяснилось, что отдельно система государственных страховых пенсий имеет дефицит в целом, заметно ниже, чем пенсионный фонд в целом из-за различных видов пенсий не по старости и непрофильных расходов.

Исследование выполнено при финансовой поддержке РФФИ в рамках научно-исследовательского проекта «Трансформация качества жизни и характеристика занятости в условиях технологических и демографических вызовов», проект № 19-310-90050.

\section{Список литературы}

1. Федеральный закон от 17.12.2001 № 173-Ф3 (ред. от 04.06.2014, с изм. от 19.11.2015) «О трудовых пенсиях в Российской Федерации». Статья 14. Размеры трудовых пенсий по старости [Электронный ресурс]. URL: http:// www.consultant.ru/document/cons_doc_LAW_34443/89a4b9 d57a9f8ca2a34736a5ad060e55936838d7/ (дата обращения: 27.11.2019).

2. Иванов С.Ф. Пенсионная реформа - 2019: детерминанты, последствия, альтернативы // Демографическое обозрение. 2019. № 6 (2). С. 6-54.

3. Заключение Комитета Государственной Думы по бюджету и налогам на проект федерального закона № 489161-7 «О внесении изменений в отдельные законодательные акты Российской Федерации по вопросам назначения и выплаты пенсий». [Электронный ресурс]. URL: http://webcache.googleusercontent.com/search?q=cache:OQvQ rpINOSUJ:kvnews.ru/upload/file/Zaklyuchenie_Komiteta_po_ byudzhetu i nalogam $1 \cdot \mathrm{doc}+\& \mathrm{~cd}=3 \& \mathrm{hl}=\mathrm{ru} \& \mathrm{ct}=\mathrm{clnk} \& \mathrm{gl}=\overline{\mathrm{ru}}$ (дата обращения: $18 . \overline{11} . \overline{2019)}$ ).

4. Вишневский А.Г. Демографический след войны. Население в рабочем возрасте и демографическая нагрузка // Демоскоп Weekly. 6-30 июня 2016. № 689-690. 
[Электронный ресурc]. URL: http://www.demoscope.ru/ weekly/2016/0689/tema08.php (дата обращения: 18.11.2019).

5. Щербакова Е.M. Старшие поколения населения России // Демоскоп Weekly. 1-27 января 2019. № 797798. [Электронный ресурc]. URL: http://www.demoscope.ru/ weekly/2019/0797/barom02.php (дата обращения: 18.11.2019).

6. Андреев Е.М., Вишневский А.Г. Ближайшие демографические перспективы России. Демографическая нагрузка на трудоспособное население // Демоскоп Weekly. 2-15 июня 2014. № 601-602. [Электронный ресурс]. URL: http://www.demoscope.ru/weekly/2014/0601/tema04.php (дата обращения: 18.11.2019)

7. Флоринская Ю.Ф., Мкртчян Н.В., Малева Т.М., Кириллова М.К. Миграция и рынок труда. М.: Книга по Требованию, 2015. 108 с.

8. Щербакова Е.М. Миграция в России, предварительные итоги 2018 года // Демоскоп Weekly. 11-24 марта 2019. № 805-806. [Электронный ресурс]. URL: http://www demoscope.ru/weekly/2019/0805/barom06.php (дата обращения: 18.11.2019).

9. Денисенко М.Б., Козлов В.А. Межпоколенческие счета и демографический дивиденд в России // Демографическое обозрение. 2018. № 5 (4). С. 6-35.

10. Силуанов: Серые зарплаты превышают 10 трлн рублей в год // Ведомости. 20 апреля 2017. [Электронный ресурс]. URL: https://www.vedomosti.ru/economics/ news/2017/04/20/686622-serie-zarplati (дата обращения: 18.11.2019).

11. Терентьева И.В. Оценка эффективности распределительной и накопительной моделей пенсионного обеспечения в России // Государственное управление. Электронный вестник. 2018. В. 70. С. 62-83.

12. Синявская О.В. История пенсионной реформы в России // История новой России. Очерки, интервью; в 3 т. под общ. ред. П.С. Филиппова. Т. 3. СПб.: Норма, 2011 C. $142-201$.

13. Кузнецова Н.В. Страховые взносы: исторические аспекты и нововведения // Политематический сетевой электронный научный журнал Кубанского государственного аграрного университета. 2016. № 123. С. 827-840.

14. Ляшок В.Ю., Назаров В.С., Орешкин М.С. Факторь роста размера пенсий в современной России // Научно-исследовательский финансовый институт. Финансовый журнал. 2016. № 1. С. 7-21.
15. Кувшинова О.В., Стеркин Ф.В., Пропопенко А.С. Сокращение числа пенсионеров позволит не сокращать размер пенсий // Ведомости. 05 мая 2017. [Электронный pecypc]. URL: https:/www.vedomosti.ru/economics/ articles/2017/05/05/688820-sokraschenie-pensionerov (дата обращения: 01.11.2019).

16. Щербакова E.M. Старшие поколения населения России. Число пенсионеров в России превысило в 2018 году 46 миллионов человек // Демоскоп Weekly. 1-27 января 2019. № 797-798. [Электронный ресурc]. URL: http://www. demoscope.ru/weekly/2019/0797/barom05.php (дата обращения: 18.11.2019).

17. Соловьев А.К. Анализ уровня бедности пенсионеров: региональные аспекты // Финансовые исследования. 2017. № 1 (54). С. 84-96.

18. Павлова Т.М. Анализ изменений государственной системы пенсионного обеспечения в России // Молодой ученый. 2017. № 49. С. 194-197. [Электронный ресурс]. URL: https:// moluch.ru/archive/183/46974/ (дата обращения: 20.11.2019).

19. Пенсионный фонд Российской Федерации. На заседании Правительства России одобрено исполнение бюджета Пенсионного фонда Российской Федерации за 2014 год. [Электронный ресурc]. URL: http://www.pfrf.ru/ press center/ 2015/05/14/90519 (дата обращения: 20.11.2019).

20. Пенсионный фонд Российской Федерации. Правительство РФ одобрило отчет об исполнении бюджета ПФР за 2016 год. [Электронный ресурc]. URL: http://www. pfrf.ru/press_center 2017/05/24/136291 (дата обращения: 20.11.2019).

21. Пенсионный фонд Российской Федерации. Правительство РФ одобрило отчет об исполнении бюджета Пенсионного фонда России за 2017 год. [Электронный ресурс]. URL: http://www.pfrf.ru/press_center 2018/05/22/159643 (дата обращения: 20.11.2019).

22. Пенсионный фонд Российской Федерации. Правительство РФ одобрило отчет об исполнении бюджета Пенсионного фонда России за 2018 год. [Электронный ресурс]. URL: http://www.pfrf.ru/press center 2019/05/23/182620 (дата обращения: 20.11.2019).

23. Зотин А.Н., Кваша М.Н. Фонд с лишним. Рейтинг самых результативных и неэффективных пенсионных служб // Коммерсантъ. 07.09.2015. № 35. С. 16.

24. Сухова С.В. Фонд или собес?// Коммерсантъ. 09.07.2018. № 25. C. 25. 